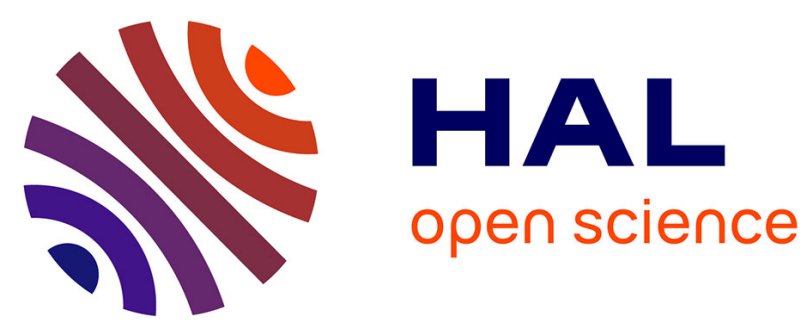

\title{
Effect of tillage on soil organic carbon mineralization estimated from C13 abundance in maize fields
}

\author{
Jérôme Balesdent, André A. Mariotti, D. Boisgontier
}

\section{To cite this version:}

Jérôme Balesdent, André A. Mariotti, D. Boisgontier. Effect of tillage on soil organic carbon mineralization estimated from C13 abundance in maize fields. The Journal of Soil Science, 1990, 41, pp.587-596. hal-02700909

\section{HAL Id: hal-02700909 \\ https://hal.inrae.fr/hal-02700909}

Submitted on 1 Jun 2020

HAL is a multi-disciplinary open access archive for the deposit and dissemination of scientific research documents, whether they are published or not. The documents may come from teaching and research institutions in France or abroad, or from public or private research centers.
L'archive ouverte pluridisciplinaire HAL, est destinée au dépôt et à la diffusion de documents scientifiques de niveau recherche, publiés ou non, émanant des établissements d'enseignement et de recherche français ou étrangers, des laboratoires publics ou privés. 


\title{
Effect of tillage on soil organic carbon mineralization estimated from ${ }^{13} \mathrm{C}$ abundance in maize fields
}

\author{
J. BALESDENT*†, A. MARIOTTI† \& D. BOISGONTIER \\ * INRA Station de Science du Sol, 78026 Versailles Cedex, France, $\dagger$ Laboratoire de Biogéochimie \\ Isotopique, INRA-Université P. et M. Curie, CNRS UA 196, T26 4E, 4 place Jussieu, 75252 Paris \\ Cedex 05 , France and $\ddagger I T C F$ Boigneville, 91720 Maisse, France
}

\begin{abstract}
SUMMARY
Three methods of cultivation, conventional tillage (CT), superficial tillage (ST) and no-tillage (NT), were applied for 17 years to continuous maize. Their effect on soil organic carbon content was investigated through measurements of carbon and ${ }^{13} \mathrm{C} /{ }^{12} \mathrm{C}$ ratios, using the natural difference in ${ }^{13} \mathrm{C}$ content between $\mathrm{C}_{3}$ plants and maize, which is a $\mathrm{C}_{4}$ plant. Because the soil had carried $C_{3}$ plants before the experiment started, the organic carbon remaining from that time $\left(\mathrm{C}_{3}\right.$-carbon), was distinguished from the carbon derived from maize. Comparison between continuous wheat and maize plots showed that organic matter from both maize and wheat decomposed without significant ${ }^{13} \mathrm{C}$ enrichment, whereas older $\mathrm{C}_{3}$-carbon was enriched by $1.5 \%$ compared to that of fresh wheat material. From the initial $3.6 \mathrm{~kg} \mathrm{C} \mathrm{m}^{-2}$ in the topsoil $(0-30 \mathrm{~cm}), 0.95$ were mineralized in the CT treatment, but only 0.45 in NT. The mineralization was the same in the tilled layer of ST as in CT. The CT treatment accumulated $1.1 \mathrm{~kg} \mathrm{C} \mathrm{m}^{-2}$ of maize-derived carbon and the NT treatment 0.8 . The mineralization of initial $\mathrm{C}_{3}$-carbon was the same at all depths between 0 and $30 \mathrm{~cm}$ in the NT treatment; $75 \%$ of the carbon derived from maize was found in the $0-5 \mathrm{~cm}$ layer.
\end{abstract}

\section{INTRODUCTION}

Tillage and annual ploughing, by stirring the soil, disrupting aggregates and increasing aeration, is known to have an effect on soil organic matter (SOM) mineralization (Rovira \& Greacen, 1957; Craswell \& Waring, 1972, Adu \& Oades, 1978). This effect cannot be quantified simply by measuring changes in SOM because cultivation also alters other factors that govern the amount of organic matter in soil, such as the annual input of organic matter and the way in which this input is incorporated. The aim of the present study was to measure the long-term effects of tillage on the degradation of the SOM originally present in the tilled topsoil before the different tillage treatments were applied. Carbon derived from maize (Zea mays L.), a $\mathrm{C}_{4}$ plant, can be distinguished from that from $C_{3}$ plants by its isotopic composition. $C_{3}$ plants have a mean $\delta^{13} \mathrm{C}$ value of $-27 \%$, whereas $C_{4}$ plants have a mean value of $-12 \% 0$ (Smith \& Epstein, 1971). This difference is maintained during the decomposition of these two sorts of plant material. When a $\mathrm{C}_{4}$ plant, such as maize, is grown on a soil that has always carried $\mathrm{C}_{3}$ plants, the $\delta^{13} \mathrm{C}$ value of the SOM can be directly related to the proportion of $\mathrm{C}_{3}$-derived carbon and $\mathrm{C}_{4}$-derived carbon in the $\mathrm{SOM}$. This natural tracer has proved to be a useful technique for studying SOM dynamics (Cerri et al., 1985; Balesdent et al., 1987; Vitorello et al., 1989). 
on loess. The original topsoil contained $22 \%$ clay (mainly illite and vermiculite), $10 \mathrm{mg} \mathrm{g}^{-1}$ organic carbon, $1.2 \mathrm{mg} \mathrm{g}^{-1}$ total $\mathrm{N}$ and had a cation exchange capacity (CEC) of $0.125 \mathrm{~mol}_{\mathrm{c}} \mathrm{kg}^{-1}$, saturated with $\mathrm{Ca}$ and $\mathrm{Mg}$. The $\mathrm{B}$ horizon contained $35 \%$ clay. The soil contained no $\mathrm{CaCO}_{3}$ in the upper $70 \mathrm{~cm}$, but $30 \%$ at $1 \mathrm{~m}$. The $\mathrm{pH}$ was neutral at the beginning of the experiment and in the tilled topsoils, but dropped to 5.2 in the uppermost layer of the non-tilled treatment. The mean annual temperature was $10.5^{\circ} \mathrm{C}$, with monthly means of $3.0^{\circ} \mathrm{C}$ in January and $18.4^{\circ} \mathrm{C}$ in July; the mean rainfall was $600 \mathrm{~mm} \mathrm{a}^{-1}$.

\title{
Tillage practices
}

The experiment contains different rotations, established in 1970, which compared continuous wheat and continuous maize. Three types of tillage practice were tested on each rotation, using four replicated blocks:

Conventional tillage (CT): ploughing to $30 \mathrm{~cm}$, followed by superficial tillage (field cultivator) and sowing;

Superficial tillage (ST): cultivation to approximately $12 \mathrm{~cm}$ with a rotavator, a field cultivator and sowing.

No-tillage (NT): direct sowing. A special seed drill with discs able to open the slit necessary for maize was developed for this experiment. Only the soil in this slit (of triangular cross-section) was tilled (approximately $10 \mathrm{~cm}$ wide $\times 7 \mathrm{~cm}$ deep)

The mean annual maize yields were $6.5 \mathrm{tha}^{-1}$ on CT, $6.2 \mathrm{tha}^{-1}$ on ST and $5.7 \mathrm{tha}^{-1}$ on NT. The yield on NT was significantly lower than on ST and CT.

Before 1970 , the field was ploughed, cultivated and sown to $C_{3}$ crops every year. except for three maize crops in the years 1962, 1964 and 1966.

\section{Sampling}

Samples were collected, in autumn, from a single plot of each treatment. From each treatment eight soil blocks $(10 \times 20 \mathrm{~cm}$ in area and $30 \mathrm{~cm}$ deep) were collected and sliced into $5-, 2-$ or $1-\mathrm{cm}$ thick layers, depending on the treatment. Soil deeper than $30 \mathrm{~cm}$ was collected with a hand auger. The corresponding layers of the eight blocks were mixed together. Wheat plots were sampled in 1985 , maize plots in 1987. Bulk density was measured by weighing the soil layers and other techniques. The litter, the $0-1 \mathrm{~cm}$ and $1-3 \mathrm{~cm}$ layers were obtained by sampling the whole layer from four squares, each of $0.1 \mathrm{~m}^{2}$; the mass per unit area of these layers was known reasonably accurately, although not their bulk density because of errors in measuring their thickness.

\begin{abstract}
Analysis
All samples were air-dried and sieved to $2 \mathrm{~mm}$; organic matter coarser than $2 \mathrm{~mm}$ was treated separately. A subsample was ground finer than $200 \mu \mathrm{m}$ for analysis. Three $\mathrm{cm}^{3}$ of $0.1 \mathrm{M} \mathrm{HCl} \mathrm{g}^{-1}$ soil were added to the samples to exclude any possible contamination by carbonates. Soil and solution were then dried together at $60^{\circ} \mathrm{C}$ before carbon or ${ }^{13} \mathrm{C}$ measurement. Carbonate-rich samples (deeper than $70 \mathrm{~cm}$ ) were decarbonated at pH 3.5. Samples of soil $(10 \mathrm{~g})$ were suspended in $100 \mathrm{~cm}^{3}$ water and the solution maintained at $\mathrm{pH} 3.5$ by continuous addition of $\mathrm{HCl}$ until stabilization. The supernatant was discarded before analysis. Total carbon was determined using dry combustion. with the evolved $\mathrm{CO}_{2}$ measured coulometrically. All results are expressed on an air-dried basis, with an oven-dry content of $97-98 \%$. The standard deviation for soil carbon measurements equalled $1 \%$ of the mean value. Indicated errors on carbon measurements were taken as two deviations, i.e. $2 \%$ of the measured value. Carbon isotope ratios were measured on $\mathrm{CO}_{2}$ obtained by combustion in a sealed quartz tube with $\mathrm{CuO}$ at $850^{\circ} \mathrm{C}$. The evolved $\mathrm{CO}_{2}$ was purified and analysed in a mass spectrometer (Finnigan Mat Delta E) fitted with a triple-ion collector and a dual inlet system equipped for rapid switching between reference and sample. The laboratory reference was calibrated against PDB, using the international standard NBS 19. Isotope ratios are expressed as $\delta^{13} \mathrm{C}$ values,
\end{abstract}




$$
\left.\delta^{13} \mathrm{C}(\% 0)=\frac{\left(R_{\text {sample }}\right.}{R_{\text {sample }}}-1\right) \times 1000,
$$

where $R=\frac{{ }^{13} \mathrm{C}}{{ }^{12} \mathrm{C}}$ and reference is $\mathrm{PDB}$.

Precision. Standard deviation on 40 measurements of a single perfectly homogenized soil sample containing both $\mathrm{C}_{3}$ and $\mathrm{C}_{4}$-derived carbon was $\pm 0.07 \% 0 \delta^{13} \mathrm{C}$. The standard deviation $\sigma$ for different samplings of a similar maize field topsoil was $\pm 0.10 \%{ }_{0} \delta^{13} \mathrm{C}$. Errors shown later were taken as $2 \sigma$, i.e. $\pm 0.2 \%_{0} \delta^{13} \mathrm{C}$.

Calculation of the proportion of organic carbon derived from maize

In order to determine the proportion $(f)$ of organic carbon originating from source $A$ in a mixture $\mathrm{A}+\mathrm{B}$ whose $\delta^{13} \mathrm{C}$ is equal to $\delta$, the following approximate formula is applied:

$$
\delta=f \delta_{\mathrm{A}}+(1-f) \delta_{\mathrm{B}}
$$

where $\delta_{\mathrm{A}}$ and $\delta_{\mathrm{B}}$ are the $\delta^{13} \mathrm{C}$ of the two sources $\mathrm{A}$ and $\mathrm{B}$, respectively.

If the total organic carbon, $C$, in the sample is known, then the amounts of carbon from the two sources are $C_{\mathrm{A}}=f C$ and $C_{\mathrm{B}}=(1-f) C$, respectively. Equation (1) can then be written:

$$
\delta=\frac{1}{C}\left(\delta_{\mathrm{A}}-\delta_{\mathrm{B}}\right) C_{\mathrm{A}}+\delta_{\mathrm{B}}
$$

In the present case, $A$ stands for the organic carbon remaining from the $\mathrm{C}_{3}$ carbon present before maize was first grown at the beginning of the experiment in 1970, and B stands for the organic carbon derived from the new plant material accumulated since 1970.

\section{RESULTS}

Soil isotopic ratios under wheat

Isotope ratios under continuous wheat were measured to estimate the $\delta^{13} \mathrm{C}$ of organic carbon from $\mathrm{C}_{3}$ origin. Carbon and $\delta^{13} \mathrm{C}$ profiles are presented in Table 1. From the data in the conventional tillage plot sampled in $1985-1987$ it can be seen that topsoil organic carbon $\left(\delta^{13} \mathrm{C}=-25.2 \%\right)$ was enriched in ${ }^{13} \mathrm{C}$ compared with plant litter $\left(\delta^{13} \mathrm{C}=-26.3 \%\right)$ and that deeper horizons were richer in ${ }^{13} \mathrm{C}$ (up to $\delta^{13} \mathrm{C}=-23.7 \%$ ) than the topsoil. The no-tillage plot also showed such enrichment; within the $0-25 \mathrm{~cm}$ layer, with originally uniform carbon and ${ }^{13} \mathrm{C}$ contents, a new profile developed with an increase in $\mathrm{C}$ at the top, where carbon inputs were higher than mineralization, and a carbon decrease at the base, where carbon inputs did not compensate for mineralization. Together with the carbon change, a new $\delta^{13} \mathrm{C}$ profile appeared with values ranging from $-24.4 \%$ at the base to $-25.8 \%$ at the top, a value close to that of the wheat itself (Table 1). The initial profile in 1970 with a mean of $-24.3 \%$ cannot be assumed to derive from pure $\mathrm{C}_{3}$ vegetation because the plot carried three maize crops in the 1960s.

Soil isotopic ratios under maize

Maize carbon has a $\delta^{13} \mathrm{C}$ value of $-12.5 \%$, as found earlier for maize plants from other locations in France (Balesdent et al., 1987). The $\delta^{13} \mathrm{C}$ profiles after 17 years of continuous maize cultivation are reported in Table 2 and Fig. 1. Fig. 1 clearly shows the enrichment in organic carbon derived from maize, its distribution with depth in the case of no tillage and the perfect homogenization in the upper $25 \mathrm{~cm}$ caused by ploughing in the CT plot and in the 10 upper $\mathrm{cm}$ in the ST plot.

\section{Relation between $\delta^{13} C$ and carbon content}

A plot of $\delta^{13} \mathrm{C}$ against the reciprocal of organic carbon content $(1 / C)$ in the different topsoil layers (Fig. 2) helps interpret the results. This type of presentation is used to examine the mixing of isotopically different components and is linear for mixtures of two components, if the first is present at a constant concentration $\left(C_{\mathrm{A}}\right.$ constant in Equation 2$)$ and the second at variable concentration. The ordinate of the line for $1 / C=0$ then indicates the $\delta^{13} \mathrm{C}$ of the second component $\left(\delta_{\mathrm{B}}\right)$. Fig. 2 
Table 1. Organic carbon and $\delta^{13} \mathrm{C}$ profiles under continuous wheat at Boigneville

\begin{tabular}{|c|c|c|c|c|c|c|}
\hline \multirow[b]{2}{*}{$\begin{array}{l}\text { Date of } \\
\text { sampling }\end{array}$} & \multicolumn{3}{|c|}{ Conventional tillage } & \multicolumn{3}{|c|}{ No tillage } \\
\hline & $\begin{array}{l}\text { Depth } \\
\text { (cm) }\end{array}$ & $\begin{array}{c}\text { Organic C } \\
\left(\mathrm{mg} \mathrm{g}^{-1} \text { soil }\right)\end{array}$ & $\begin{array}{l}\delta^{13} \mathrm{C} \\
(\% 0)\end{array}$ & $\begin{array}{l}\text { Depth } \\
(\mathrm{cm})\end{array}$ & $\begin{array}{c}\text { Organic C } \\
\left(\mathrm{mg} \mathrm{g}^{-1} \text { soil) }\right.\end{array}$ & $\begin{array}{l}\delta^{13} \mathrm{C} \\
(\% 0)\end{array}$ \\
\hline 1970 & $0-5$ & 9.9 & -24.5 & & & \\
\hline id. & $10-15$ & 9.8 & -24.2 & & & \\
\hline id. & $20-25$ & 8.4 & -24.3 & & & \\
\hline 1987 & wheat straw & & -26.3 & & & \\
\hline 1985 & $0-5$ & 11.1 & -25.4 & $0-1$ & 23.0 & -25.8 \\
\hline id. & & & & $3-5$ & 13.1 & -25.1 \\
\hline id. & $5-10$ & 11.2 & -25.2 & $5-10$ & 10.1 & -24.7 \\
\hline id. & $10-15$ & 11.5 & -25.2 & $10-15$ & 9.0 & -24.4 \\
\hline id. & $15-20$ & 11.4 & -25.2 & $15-20$ & 8.8 & -24.4 \\
\hline id. & $20-25$ & 10.7 & -25.1 & $20-25$ & 8.3 & -24.6 \\
\hline id. & $25-30$ & 9.8 & -25.2 & $25-30$ & 5.7 & -24.5 \\
\hline id. & $30-35$ & 5.0 & -24.7 & & & \\
\hline 1987 & $30-50$ & 4.4 & -24.8 & & & \\
\hline id. & $50-70$ & 3.5 & -24.6 & & & \\
\hline id. & $70-90$ & 3.6 & -24.1 & & & \\
\hline id. & $90-110$ & 2.9 & -23.7 & & & \\
\hline
\end{tabular}

shows such linear relations for NT plots, whose contents varied across a wide range, for both wheat and maize. The lines crossed the $y$-axis close to the values measured for plant material: the two regressions, made without including the measured values for plant material, gave a correlation of 0.97 and an intercept of $-26.5 \%$ ( $\pm 0.6 \%$ for its $95 \%$ confidence interval) for wheat; the corresponding values for maize were 0.995 and $-13.1 \%$ o $\pm 0.9 \%$.

The distribution of $\delta^{13} \mathrm{C}$ through the organic carbon in the topsoil indicates the existence of two pools, the first present at a constant concentration, the second present in variable amounts with the same $\delta^{13} \mathrm{C}$ as the vegetation itself. The lines shown in Fig. 2 were obtained from regressions that included the point measured for plant material; the point where the two lines cross can be considered as defining the organic carbon that is common to the maize field and the wheat field, i.e. the organic carbon of $\mathrm{C}_{3}$ origin remaining from the beginning of the experiment in 1970 . From Fig. 2, the initial carbon content of the soil on both experiments must have been $C_{\mathrm{A}}=8.0 \mathrm{mg} \mathrm{Cg}^{-1}$ soil with $\delta_{A}=-24.3 \%$, for the NT treatment.

In the case of conventional tillage, the points are not on the same lines as with NT. The lines cross at a different point, namely $C_{\mathrm{A}}=6.5 \mathrm{mg} \mathrm{g}^{-1}, \delta_{\mathrm{A}}=-24.5 \%$. With ST, the points in the top $15 \mathrm{~cm}$ are close to the line obtained for CT and the points of the $15-30 \mathrm{~cm}$ layers close to the line of NT. The $\delta^{13} \mathrm{C}$ of organic carbon remaining from the $\mathrm{C}_{3}$ carbon present in 1970 , therefore, could be determined accurately in the present experiment and did not appear to differ with the treatments. The mean value, $-24.4 \%$ can be used as $\delta_{\mathrm{A}}$ in Equation (1) to calculate the quantities of organic matter derived from maize. The $\delta^{13} \mathrm{C}$ of maize-derived organic matter $\left(\delta_{\mathrm{B}}\right.$ in Equation 1$)$ was taken as that of the maize material itself, namely $-12.5 \%$. The data in Fig. 2 (linear relationships with estimated value of $-13.1 \%$ for maize-derived carbon) strongly suggest that no isotopic enrichment occurred during humification. This will be further discussed later. In any case, a small bias in the estimation of $\delta_{\mathrm{B}}$ would not greatly affect the calculation of $f$ in the present study. 
Tillage and $C$ mineralization

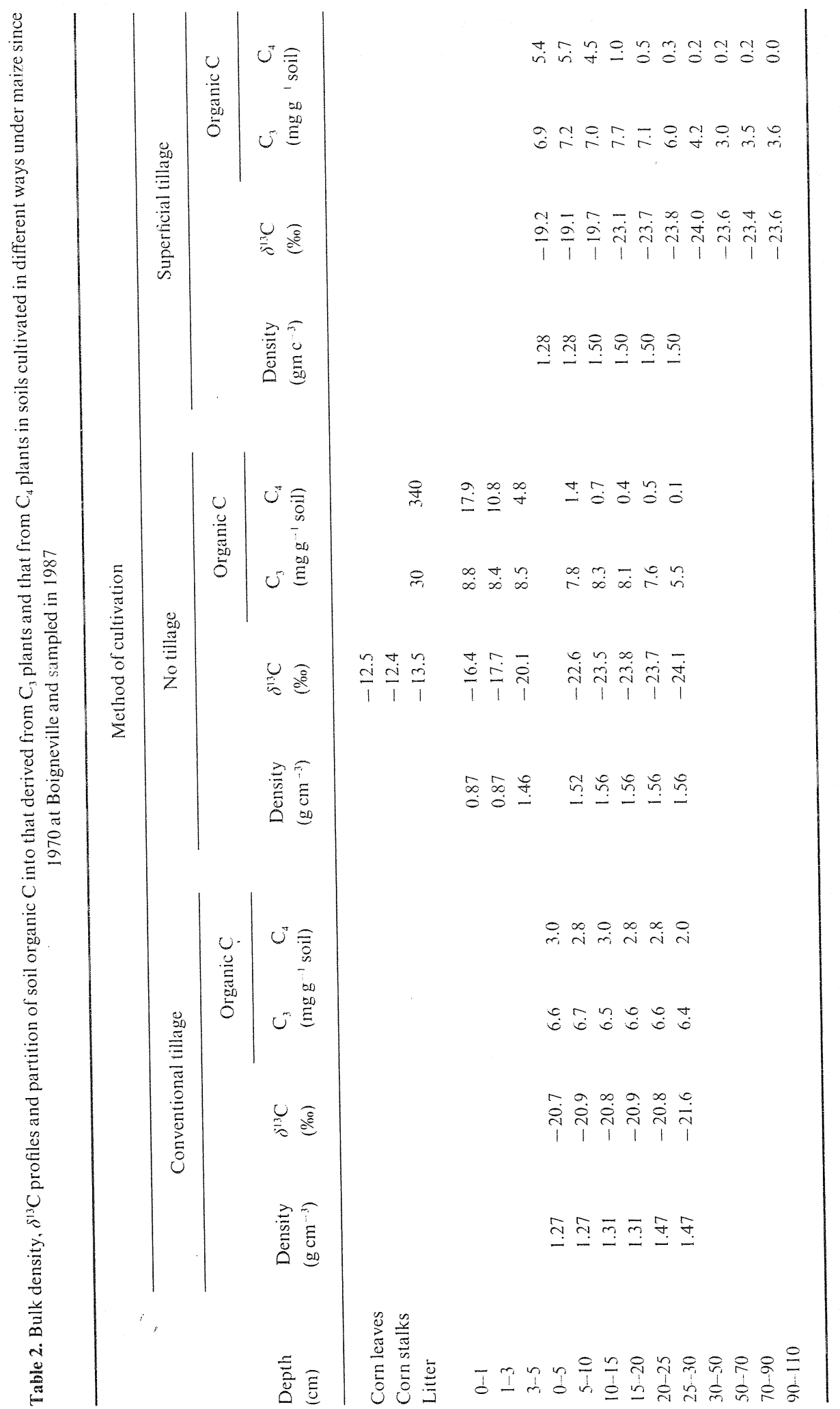




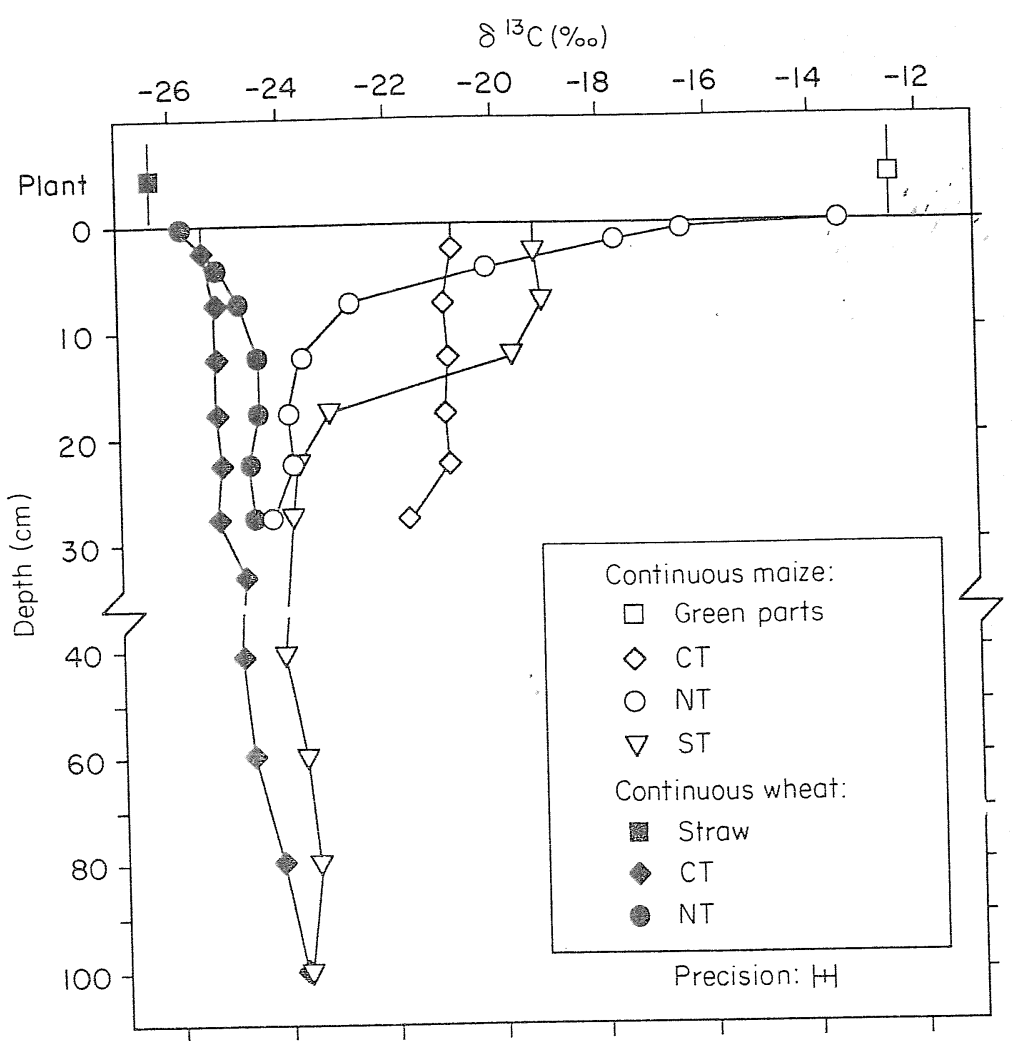

Fig. 1. Profiles of $\delta^{13} \mathrm{C}$ of plant material and soil organic carbon after 17 years of continuous maize and 15 years of wheat cultivation with different tillage practices at Boigneville (CT: conventional tillage; NT: no tillage: ST: superficial tillage).

Stocks of organic carbon of both origins

Table 2 gives the concentrations of organic carbon derived from maize plant material that have accumulated since 1970 and also the $\mathrm{C}_{3}$-carbon remaining from the initial organic carbon present at the beginning of the experiment as calculated by Equation (1), using the values for $\delta_{\mathrm{A}}$ and $\delta_{\mathrm{B}}$ given above. The stocks of carbon held in soils from the different tillage treatments must be compared on the basis of equal soil masses, not depths, to allow for the differing effects of tillage on bulk density. Bulk density was much higher with no tillage, where compaction caused by machinery was never disrupted (Table 2). The profiles for $\mathrm{C}_{3}$-carbon are presented in Fig. 3, with the cumulative mass of soil down the profile as $y$-axis. It is worth noting that the ploughing depth in CT increased from $25 \mathrm{~cm}$ in 1970 to approximately $29 \mathrm{~cm}$ in 1987, causing a dilution of organic carbon in the topsoil by deeper soil with a lower carbon content.

The total stocks in the layer containing the upper $400 \mathrm{~kg}$ soil $\mathrm{m}^{-2}$, whose base is below the deepest plough layer, were calculated from the data of Table 2 . The stock of $\mathrm{C}_{3}$-carbon decreased in the order NT $>$ ST $>$ CT (Table 3). While $0.45 \mathrm{~kg} \mathrm{C} \mathrm{m}^{-2}$ were mineralized in the no-tillage plot, $0.95 \mathrm{~kg} \mathrm{C} \mathrm{m}^{-2}$ were mineralized in the conventional tillage plot. On the other hand, the stock of maize-derived carbon was lower in NT than in CT and ST.

\section{DISCUSSION}

${ }^{13} \mathrm{C}$ content of soil organic carbon from $C_{3}$ vegetation

Soil organic matter from $\mathrm{C}_{3}$ vegetation is known to be heterogeneous, the measured $\delta^{13} \mathrm{C}$ values of different constituents varying by as much as 3 to $4 \%$. The carbon remaining after partial mineralization can differ from the initial carbon, generally being richer in ${ }^{13} \mathrm{C}$. This is in accord with the higher 


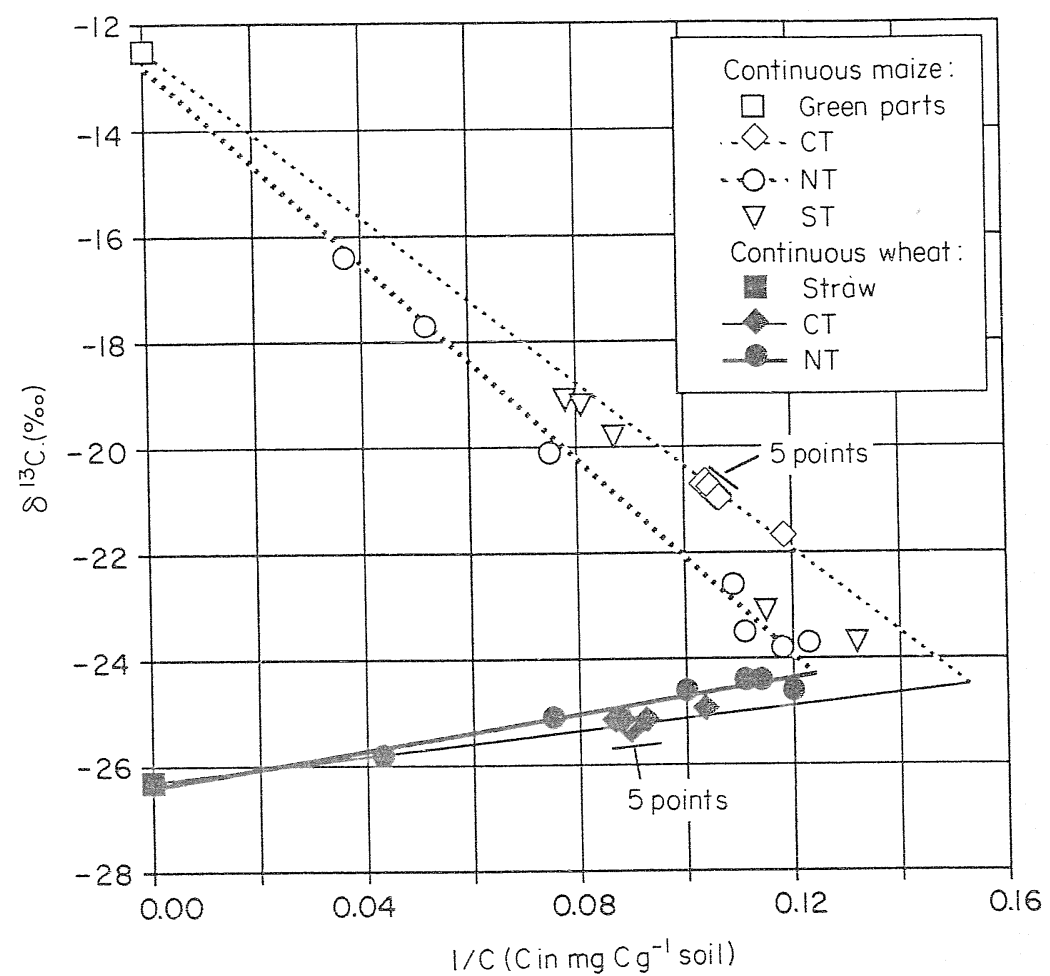

Fig. 2. Relationship between $\delta^{13} \mathrm{C}$ and reciprocal of carbon content in the different layers of the topsoil $(0-25 \mathrm{~cm})$ after 17 years of continuous maize and 15 years of wheat cultivation with different tillage practices at Boigneville (CT: conventional tillage; NT: no tillage; ST: superficial tillage).

${ }^{13} \mathrm{C}$ content of soil organic matter than of plant material, as well as the increase of ${ }^{13} \mathrm{C}$ with depth, as seen above in the experiment with wheat. This feature is well known in aerated soils that are assumed to have been under pure $C_{3}$ vegetation, and has been described by several authors (O'Brien $\&$ Stout, 1978; Volkoff \& Cerri, 1987; Natelhoffer \& Fry, 1988); it is usually attributed to humification processes. The $\delta^{13} \mathrm{C}$ is always correlated with the age of SOM, and three main processes can explain enrichment (Balesdent et al., 1987); (i) isotopic fractionation associated with microbial respiration or fermentation, leading to an enrichment of microbial products, compared to plant material (Macko \& Estep, 1984); (ii) faster mineralization of ${ }^{13} \mathrm{C}$-poorer components (Nissenbaum \& Schallinger, 1974; Benner et al., 1987): (iii) decrease in the $\delta^{13} \mathrm{C}_{\text {of }} \mathrm{CO}_{2}$ or vegetation with time in the past. The $\delta^{13} \mathrm{C}$ decrease in atmospheric $\mathrm{CO}_{2}$ over the last 150 years is a result of fossil fuel combustion or additional SOM mineralization-the Suess effect. It is responsible for the difference of at least $1.3 \%$, or locally more, between century-old organic carbon and present vegetation (Friedli et al., 1984; Stuiver \& Braziunas, 1987).

The new profile developed under no-tillage wheat can provide information about this ${ }^{13} \mathrm{C}$ heterogeneity. The soil carbon accumulated from wheat over 15 years has a mean $\delta^{13} \mathrm{C}$ value of $-26.5 \pm 0.6 \%$, which is very near to that of the wheat straw analysed $(-26.3 \%)$. The same trend was observed for maize-derived material: the rather similar behaviour of maize and wheat during decomposition (Broder \& Wagner, 1988) is unlikely to involve different isotopic processes. From models such as that of Jenkinson \& Rayner (1977), it can be calculated that the wheat-derived carbon accumulated over 15 years represents 15 to $20 \%$ of the total input to the soil. The mineralization of more than $80 \%$ of the plant material has induced no significant enrichment. On the other hand, the carbon remaining from the initial carbon was shown to have a $\delta^{13} \mathrm{C}$ close to $-24.4 \%$. This carbon is mainly of $C_{3}$ origin: the carbon remaining from the three maize crops grown in the 1960's could represent 3 to $6 \%$ of this carbon and thus increase the $\delta^{13} \mathrm{C}$ of $C_{3}$-carbon by 0.3 to $0.6 \%$. The 


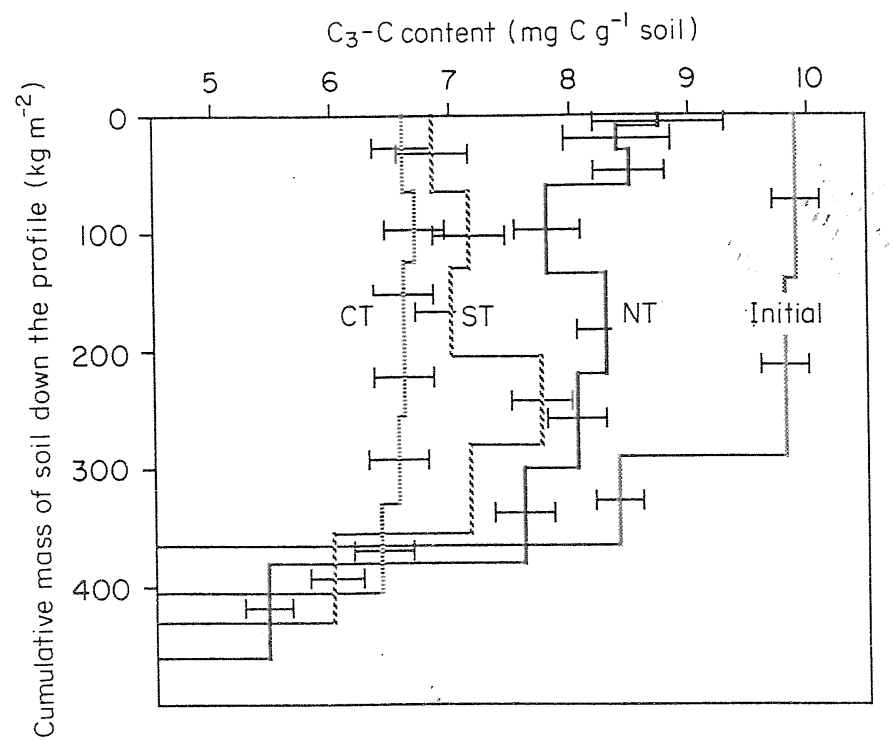

Fig. 3. Profiles of initial organic $\mathrm{C}$, and $\mathrm{C}$ remaining from the initial carbon after 17 years of continuous maize cultivation with different tillage practices at Boigneville (CT: conventional tillage; NT: no tillage; ST: superficial tillage). The $y$-axis is the cumulative mass of soil down the profile. Bars were obtained from the calculated error, based on estimated error ( $95 \%$ confidence interval) on $C$ and $\delta^{13} \mathrm{C}$ measurements of soil samples.

Table 3. Stocks of organic carbon of both origins within the upper $400 \mathrm{~kg} \mathrm{soil} \mathrm{m}^{-2}$ in 1970 and after 17 years of continuous maize with different methods of cultivation at Boigneville

\begin{tabular}{|c|c|c|c|c|}
\hline & \multirow[b]{2}{*}{1970} & \multicolumn{3}{|c|}{$\begin{array}{c}1987 \\
\text { Method of cultivation }\end{array}$} \\
\hline & & Conventional & No & Superficial \\
\hline aEquivalent depth (cm) & $0-27$ & $0-30$ & $0-26$ & $0-28$ \\
\hline Total carbon $\left(\mathrm{kg} \mathrm{m}^{-2}\right)$ & 3.60 & 3.70 & 3.95 & 4.00 \\
\hline $\mathrm{C}_{3}$-carbon $\left(\mathrm{kg} \mathrm{m}^{-2}\right)$ & 3.60 & 2.65 & 3.15 & 2.80 \\
\hline Maize carbon $\left(\mathrm{kg} \mathrm{m}^{-2}\right)$ & 0.00 & 1.10 & 0.80 & 1.20 \\
\hline
\end{tabular}

${ }^{a}$ Depth containing $400 \mathrm{~kg}$ soil $\mathrm{m}^{-2}$.

$\mathrm{C}_{3}$-carbon would then have had a $\delta^{13} \mathrm{C}$ between -24.7 and -25.0 , if no maize had been grown before 1970 . This carbon has a probable mean age of several centuries and can contain carbon that is thousands of years old (Balesdent \& Guillet, 1982), with a high ${ }^{13} \mathrm{C}$ content, like that found in the deeper horizons. These results suggest that the Suess effect can explain most of the differences between plant material and topsoil, and that the further ${ }^{13} \mathrm{C}$ enrichment observed here reflects either the ultimate products of humification or very old organic matter derived from vegetation with unknown initial $\delta^{13} \mathrm{C}$. Nateihoffer \& Fry (1988) also showed that the $\delta^{13} \mathrm{C}$ of organic matter accumulated from oak litter over 30 years was not very different from that of the litter itself, but that older soil carbon was much richer.

An unbiased estimate of the $\delta^{13} \mathrm{C}$ of the carbon remaining from the initial $\mathrm{C}_{3}$ carbon is necessary if $\mathrm{C}_{3}$ to $\mathrm{C}_{4}$ vegetation changes are to be used to study soil organic matter dynamics. This value can be 
estimated from a $\mathrm{C}_{3}$ soil kept bare throughout the experiment, or from the relation between carbon concentration and $\delta^{13} \mathrm{C}$ down the profile of a similar soil under $\mathrm{C}_{3}$ vegetation, as used in the present study.

Distribution of organic carbon from maize

The quantity of organic carbon accumulated in the topsoil $(0-30 \mathrm{~cm})$ over the 17 years of maize cultivation ranged from 0.8 to $1.2 \mathrm{~kg} \mathrm{~m}^{-2}$ (Table 3 ); the mean annual accumulation was $60 \mathrm{~g} \mathrm{C} \mathrm{m}^{-2}$. Comparison of the different tillage treatments is difficult because of the difference in mean annual yields and in dry matter production. The difference is, nevertheless, more important than would have been expected from the comparatively small differences in above-ground productivity; accumulation of carbon in soil was markedly lower with no tillage. This can be explained by the degradation of most of the material in the litter, above the soil surface, away from the protection of the soil minerals. Mixing in the ploughed plot led to a perfectly uniform vertical distribution of organic carbon from maize. With NT, $75 \%$ of the organic carbon returned from maize to the 0-30 $\mathrm{cm}$ layer can be found in the uppermost $5 \mathrm{~cm}$. Despite the low precision, the deeper layers (30 to $80 \mathrm{~cm}$ ) received some $10-20 \%$ of the total returns of maize C.

\section{Effect of tillage on SOM mineralization}

It can be seen from Table 3 and Fig. 3 that mineralization of the initial organic carbon during the experiment was doubled in the conventional tillage plot compared with the no-tillage plot. The organic carbon, which was more slowly mineralized in the absence of tillage, can be considered as 'physically protected' as defined by Rovira \& Greacen (1957). It was present in essentially small quantities because the soil was ploughed annually before the experiment started, but it might be much higher in systems that had not been tilled for a long time (Balesdent et al., 1988). The effect of superficial tillage (ST) was the same as that of conventional tillage, but affected only the tilled layer, which was approximately $12 \mathrm{~cm}$ deep. Comparison between the $\mathrm{C}_{3}$-carbon concentrations of ST and NT plots did not depend on any effect of dilution with deeper carbon, or on the precision of bulk density measurements, as in the CT plot, where the depth of ploughing increased from approximately $25 \mathrm{~cm}$ in 1970 to $29 \mathrm{~cm}$ in 1987. Although the mineralization rate was lower in the NT treatment than in the CT treatment, the returns of maize carbon were also lower, so that the final total carbon content was similar in both treatments. The age distribution of SOM was nevertheless different. This is consistent with the results of Staley et al. (1988), who showed that the effect of a tillage practice on soil organic matter dynamics and nutrient mineralization depended greatly on the number of years under the tillage method.

The uniform profile of $\mathrm{C}_{3}$ organic carbon in the NT treatment (Fig. 3) also shows that the extent of mineralization was approximately the same in the top layers as in the 10-25 cm layers, despite the difference in physical and chemical conditions such as temperature, water content, aeration, annual freezing cycles and $\mathrm{pH}$. Similarly, there is no suggestion that the relatively large returns of organic matter received by the surface layers, compared to the deeper layers, has induced a 'priming effect', which would accelerate the decomposition of $\mathrm{C}_{3}$ organic $\mathrm{C}$ in the upper part of the soil profile.

The nature of tillage practices has to be taken into account in models of SOM dynamics. The general decrease in SOM content that has been observed in France in the 1960's and 1970's was classically related to the lower carbon inputs associated with the decrease of stock farming, cattle manure use and meadow area. It has also to be related to the increasing energy applied to tillage (Fardeau et al., 1988) with the use of machines such as power harrows. This SOM decrease could have contributed as much to groundwater nitrate enrichment as the use of high fertilizer rates has done.

\section{ACKNOWLEDGEMENTS}

We wish to thank M. Bodet and M. Couture of the Institut Technique des Céréales et des Fourrages for their help in this study, Marie-France Commeau for revision of the English manuscript, the referees and the Associate Editor for improvements to the manuscript. 


\section{REFERENCES}

ADU, J.K. \& OADES, J.M. 1978. Physical factor influencing decomposition of organic materials in soil aggregates. Soil Biology and Biochemistry $\mathbf{1 0}$, 109-115.

Balesdent, J. \& Guillet, B. 1982. Les datations pa le ${ }^{14} \mathrm{C}$ des matières organiques des sols. Contribution à l'étude de l'humification et du renouve lement des substances humiques. Science du Sol 2 93-112.

Balesdent, J., Mariotti, A. \& Guillet, B. 1987. Natural ${ }^{13} \mathrm{C}$ abundance as a tracer for soil organic matter dynamics studies. Soil Biology and Biochemistry 19, 25-30.

Balesdent, J., Wagner, G.H. \& Mariotti, A. 1988 Soil organic matter turnover in long-term field experiments as revealed by the carbon-13 natura abundance. Soil Science Society of America Journal 52, 118-124.

Benner, R., Fogel, M.L., Sprague, E.K. \& Hodson, R.E. 1987. Depletion of $13 \mathrm{C}$ in lignin and its implications for stable carbon isotope studies. Nature 329, 708-710.

BoIsGONTIER, D. 1982. Matière organique, simplification du travail du sol et irrigation. Perspectives Agricoles 64, 16-26.

Broder, M.W. \& WAGNER, G.H. 1988. Microbial colonization of maize, wheat and soybean residue. Soil Science Society of America Journal 52, 112-117.

Cerri, C., Feller, C., Balesdent, J., Victoria, R. \& Plenecassagne, A. 1985. Application du traçage isotopique naturel en ${ }^{13} \mathrm{C}$ à l'étude de la dynamique de la matière organique dans les sols. Comptes Rendus de l'Académie des Sciences de Paris T.300,II,9, 423-428.

Craswell, E.T. \& Waring, S.A. 1972. Effect of grinding on the decomposition of soil organic matter. II. Oxygen uptake and nitrogen mineralization in virgin and cultivated cracking clay soils. Soil Biology and Biochemistry 4, 435-442.

Fardeau, J.C., Guiraud, G., Thiery, J., Morel, C. \& BOUCHER, B. 1988. Taux net de minéralisation de la matière organique des sols de grande culture de Beauce: conséquences pour l'azote. Comptes Rendus de l'Académie d'Agriculture de France 74 (8), $61-70$

Friedli, H., MoOr, E., Oeschger, H., Siegenthaler,
U. \& Stauffer, B. $1984 .{ }^{13} \mathrm{C} /{ }^{12} \mathrm{C}$ ratios in $\mathrm{CO}_{2}$ extracted from Antarctic ice. Geophysical Research Letters 11, 1145-1148.

JENKINSON, D.S. \& RAYNER, J.H. 1977. The turnover of soil organic matter in some of the Rothamsted classical experiments. Soil Sciénce 123, 298-305.

Macko, A. \& Estep, M.L.F. 1984. Microbial alteration of stable nitrogen and carbon isotopic compositions of organic matter. Organic Geochemistry 6, 787-790.

NATElHofFer, K.J. \& Fry, B. 1988. Controls on natural nitrogen-15 and carbon-13 abundance in forest soil organic matter. Soil Science Society of America Journal 52, 1633-1640.

Nissenbaum, A. \& SChallinger, K.M. 1974. The distribution of the stable carbon isotope $\left({ }^{13} \mathrm{C} /{ }^{12} \mathrm{C}\right)$ in fractions of soil organic matter. Geoderma 11 , 137-145.

O'Brien, B.J. \& SouT, J.D. 1978. Movement and turnover of soil organic matter as indicated by carbon isotope measurements. Soil Biology and Biochemistry 10, 309-317.

ROVIRA, A.D. \& GREACEN, E.L. 1957. The effect of aggregate disruption on the activity of microorganisms in the soil. Australian Journal of Agricultural Research 8, 659-673.

SMITH, B.N. \& Epstein, S. 1971. Two categories of ${ }^{13} \mathrm{C} /{ }^{12} \mathrm{C}$ ratios for higher plants. Plant Physiology 47 , 380-384.

Staley, T.E., Edwards, W.M., Scott, C.L. \& OWENS, L.B. 1988. Soil microbial biomass and organic component in a no-tillage chronosequence. Soil Science Society of America Journal 52, 998-1005.

Stuiver, M. \& Braziunas, T.F. 1987. Tree cellulose $13 \mathrm{C} / 12 \mathrm{C}$ isotope ratios and climatic change. Nature 328, 58-60.

Vitorello, V.A., Cerri, C.C., Andreux, F., Feller, C. \& ViCTORIA, R.L. 1989. Organic matter and natural carbon-13 distribution in forested and cultivated Oxisols. Soil Science Society of America Journal 53, 773-778.

VolkofF, B. \& CerRI, C. 1987. Carbon isotopic fractionation in subtropical grasslands soils. Comparison with tropical forest soils. Plant and Soil 102 $27-31$.

(Received 21 December 1989; accepted 18 July 1990) 